\title{
Mechanism of gonadotropin-releasing hormone (GnRH)-I and -II-induced cell growth inhibition in ovarian cancer cells: role of the GnRH-I receptor and protein kinase C pathway
}

\author{
Ki-Yon Kim, Kyung-Chul Choi, Nelly Auersperg and Peter C K Leung
}

Department of Obstetrics and Gynecology, British Columbia Children's and Women's Hospital, Child and Family Research Institute, University of British Columbia, 2H-30, 4490 Oak St Vancouver, Vancouver, British Columbia, Canada, V6H 3V5

(Requests for offprints should be addressed to P C K Leung; Email: peleung @interchange.ubc.ca)

\begin{abstract}
In our previous studies, we demonstrated that ERK1/2 (extracellular signal-regulated protein kinase) and p38 MAPK (mitogen-activated protein kinase) are required for gonadotropin-releasing hormone $(\mathrm{GnRH})$-II-induced anti-proliferation of ovarian cancer cells. In the present study, we examined the role of the GnRH-I receptor, as well as the activation of protein kinase C (PKC), in the antiproliferative effect induced by GnRH-I or II in ovarian cancer cells. Our results demonstrated that Antide, a GnRH-I antagonist, reversed the activation of ERK $1 / 2$ induced by GnRH-I or II and abolished the anti-proliferative effect of $\mathrm{GnRH}-\mathrm{I}$ and II in ovarian cancer cells. Transfection of shortinterfering RNA to abrogate the gene expression of the $\mathrm{GnRH}-\mathrm{I}$ receptor reversed $\mathrm{GnRH}-\mathrm{I}$ and IIinduced anti-proliferation. These results indicate that $\mathrm{GnRH}-\mathrm{I}$ or II induce anti-proliferation through the GnRH-I receptor in ovarian cancer cells. In addition, the activation of ERK $1 / 2$ by GnRH-I or II was mimicked by phorbol-12-myristate 13-acetate, a PKC activator. Pretreatment with GF109203X, an inhibitor of PKC, blocked GnRH-induced ERK1/2 activation and anti-proliferation. These results suggest that the activation of PKC is responsible for GnRH-induced ERK1/2 activation and antiproliferation in ovarian cancer cells. Taken together, these results indicate that binding of $\mathrm{GnRH}-\mathrm{I}$ and II to the GnRH-I receptor activates ERK1/2 through a PKC-dependent pathway and is essential for $\mathrm{GnRH}$-induced anti-proliferation of ovarian cancer cells.
\end{abstract}

Endocrine-Related Cancer (2006) 13 211-220

\section{Introduction}

Gonadotropin-releasing hormone $(\mathrm{GnRH})$ is a key regulator in the hypothalamus-pituitary-gonadal axis which regulates the reproduction of vertebrates. In addition to its well known physiological role in the regulation of gonadotropin secretion from the pituitary, GnRH has been shown to exert direct antiproliferative effect on ovarian cancer cells (Choi et al. 2001a, Grundker et al. 2002, Grundker \& Emons 2003, Rzepka-Gorska et al. 2003). Recently, a novel form of GnRH (referred to GnRH-II, to distinguish it from the classical mammalian form of GnRH, i.e., GnRH-I) has been identified in the human (White et al. 1998). There is some preliminary evidence that GnRH-II induces a stronger anti-proliferative effect than GnRH-I in ovarian cancer cells (Grundker et al. 2002).

The GnRH-I receptor is a member of the G proteincoupled receptors (GPCR) family and its mRNA is expressed in most primary ovarian tumors (Irmer et al. 1995, Sealfon et al. 1997). The human GnRH-II receptor mRNA is also expressed in various tissues (Neill et al. 2001). Furthermore, it has been suggested that the signal transduction pathways coupled to the GnRH-II receptor may be different from those triggered by activation of the GnRH-I receptor (Millar et al. 2001, Neill et al. 2001). Nevertheless, direct evidence demonstrating the existence of a 
full-length, functional GnRH-II receptor RNA transcript in human tissues is lacking and the issue of whether the GnRH-I receptor mediates the effects of both GnRH-I and II remains unresolved.

Our previous studies showed that the antiproliferative effect of GnRH-II are mediated by the ERK1/2 (extracellular signal-regulated protein kinase) and p38 MAPK (mitogen-activated protein kinase) pathways (Kim et al. 2004, 2005). MAPKs are activated in response to mitogens and growth factors, and play an important role in the control of cell growth and differentiation. Diverse mechanisms have been proposed for MAPK activation through GPCRs (Crespo et al. 1994, Ohmichi et al. 1994) and GnRH-I activates MAPK in various cell types including ovarian cancer cells (Kraus et al. 2001, Grundker \& Emons 2003). However, there is little information on the mechanism of MAPK activation by GnRH in ovarian cancer.

The activation of PKC and MAPK in response to diverse stimuli is known to regulate cell growth and differentiation. Many GPCRs can activate ERK1/2 and the activation of PKC is an important event in the activation of ERK1/2 by GnRH in pituitary cells (Harris et al. 1997). In addition, GnRH-I-stimulated ERK $1 / 2$ activation was shown to be mediated through PKC activation in human granulosa-luteal cells (Kang et al. 2001b). However, it has also been reported that GnRH signaling is independent of PKC in COS7 cells (Kimura et al. 1999), suggesting that GnRH-I signaling may vary by cell type. A better understanding of the mechanism of action of GnRH and the elucidation of the signal transduction pathways controlling anti-proliferation and apoptosis are essential to the development of novel and efficient therapies for ovarian cancer. Considering that the intracellular signals generated by GnRH are still poorly understood in ovarian cancer, we investigated the role of the GnRH-I receptor and PKC in GnRH-I and II-induced ERK1/2 activation and anti-proliferation in ovarian cancer cells.

\section{Materials and Methods}

\section{Cell culture}

Human ovarian adenocarcinoma cell lines, OVCAR-3 and SKOV-3, were cultured as previously described (Kang et al. 2000b, Choi et al. 2001b, Kim et al. 2004). Briefly, the cells were cultured in medium 199:MCDB 105 (1:1, Sigma, St Louis, MO, USA) supplemented with 10\% FBS (Hyclone, Logan, UT, USA), $100 \mathrm{U} / \mathrm{ml}$ penicillin $\mathrm{G}$ and $100 \mu \mathrm{g} / \mathrm{ml}$ streptomycin (Life Technologies, Inc., Rockville, MD, USA) in a humidified atmosphere of $5 \% \mathrm{CO}_{2}-95 \%$ air at $37^{\circ} \mathrm{C}$. Cells were washed once with medium and serum starved overnight before treatment with GnRH-I agonist, (D-Trp6)-GnRH (Sigma), GnRH-II analog, D-Arg(6)-Azagly(10)-NH2 (Peninsula laboratories, Belmont, CA, USA) or phorbol 12-myristate 13-acetate (TPA; Sigma).

\section{Immunoblot analysis}

To investigate the involvement of the GnRH-I receptor in GnRH-I and II-induced ERK1/2 activation, cells were seeded at a density of $2 \times 10^{5}$ cells in $35 \mathrm{~mm}$ dishes and cultured for 2 days. The cells were pre-treated with Antide $(100 \mathrm{nM})$ for $15 \mathrm{~min}$ and then treated with GnRH-I or II $(100 \mathrm{nM})$ for $10 \mathrm{~min}$. Immunoblot analysis was carried out as previously described (Kang et al. 2001a, Kim et al. 2004). Briefly, $35 \mu \mathrm{g}$ of total protein was run on a $10 \%$ SDS-PAGE gel and transferred to nitrocellulose membrane. The membrane was immunoblotted using a mouse monoclonal antibody for phosphorylated ERK1/2 (P-ERK1/2; New England Biolabs, Inc., Pickering, ON, Canada). Alternatively, the same membrane was probed with a rabbit polyclonal antibody for ERK1/2 to detect total ERK1/2 (T-ERK1/2; phosphorylation-state independent). Signals were detected with horseradish peroxidase (HRP)-conjugated secondary antibody and visualized using the enhanced chemiluminescence kit (ECL; Amersham Pharmacia Biotech Inc., Oakville, ON, USA). The intensity of signals was quantified by densitometry (BioDocAnalyze, Biometra, Göttingen, Germany). The activity of ERK $1 / 2$ is presented as a ratio of P-ERK1/2 to T-ERK1/2. To explore the role of PKC activation in GnRH-I or II-induced ERK1/2 activation, cells were pretreated with the PKC specific inhibitor, GF109203X ( $3 \mu \mathrm{M})$ for $30 \mathrm{~min}$, followed by treatment with GnRH-I or -II $(100 \mathrm{nM})$.

\section{In vitro transfection with small interfering RNAs (siRNAs) targeting the GnRH-I receptor}

GnRH-I receptor siRNAs were synthesized by Invitrogen (Burlington, ON, Canada), and the sequences were as follows: hGnRH-I-RS (5'-GCUCU CUGCG ACCUU UAAU- $3^{\prime}$ ), and hGnRH-I-RA ( $5^{\prime}$-AUUAA AGGUC GCAGA GAGC-3'). In addition, a nonspecific scrambled siRNA was purchased from Invitrogen used as a control and the sequences were as follows: S (5'-GCUUC CGAGC CUUUC UAAU- $3^{\prime}$ ) and A ( $5^{\prime}$-AUUAG AAAGG CUCGG AAGC- $\left.{ }^{\prime}\right)$. The siRNA transfection was performed according to the manufacturer's suggested procedure (Invitrogen). In brief, 1 day before transfection, $2 \times 10^{4}$ cells per well 
of a 6-well plate were seeded in $2 \mathrm{ml}$ of culture medium or $4 \times 10^{4}$ cells per well of a 24 -well plate were seeded in $500 \mu \mathrm{l}$. The cells were transfected with GnRH-I receptor $(12.5 \mathrm{pM}$ final concentration) or scrambled siRNA with $1 \mu 1$ lipofectamine 2000 reagent, following the manufacturer's protocol. Then, the cells were challenged with GnRH-I or -II for $24 \mathrm{~h}$. To monitor the siRNA transfection efficiency, immunoblot analysis was performed using GnRH-I receptor antibody (Neomarkers, Fremont, CA, USA).

\section{Thymidine incorporation assay}

Cell proliferation was monitored using $\left[{ }^{3} \mathrm{H}\right]$ thymidine incorporation as previously described (Choi et al. 2001a, Choi et al. 2001b, Kang et al. 2001a). Briefly, $4 \times 10^{4}$ OVCAR-3 or SKOV-3 cells were plated in 24-well dishes in $0.5 \mathrm{ml}$ of medium as described above. After $24 \mathrm{~h}$ of incubation the cells were treated with a final concentration of $100 \mathrm{nM}$ GnRH-I or II for $24 \mathrm{~h}$. Following treatment, the cells were then incubated with medium containing $1 \mu \mathrm{Ci}\left[{ }^{3} \mathrm{H}\right]$ thymidine $(0.5 \mathrm{Ci} /$ mmol; Amersham Pharmacia Biotech Inc.) and collected $6 \mathrm{~h}$ later. In order to block the activation of GnRH-I receptor or PKC, the cells were pretreated with Antide $(100 \mathrm{nM})$ or GF109203X (0.03, 0.3 or $3 \mu \mathrm{M})$ for $15 \mathrm{~min}$. The cells were transfected with siRNA targeting the GnRH-I receptor $24 \mathrm{~h}$ prior to treatment with GnRH-I or -II.

\section{Statistical analysis}

The data from three separate experiments are presented as the mean \pm s.D. Each individual experiment was performed in duplicate or triplicate. Statistical analysis was performed by one-way ANOVA followed by Tukey's multiple comparison test. $P<0.05$ was considered statistically significant.

\section{Results}

\section{Effect of a GnRH-I antagonist on GnRH-I and II-induced ERK1/2 activation and cell proliferation}

OVCAR-3 and SKOV-3 cells were treated with GnRH-I or II (100 nM) and ERK1/2 phosphorylation was measured after $10 \mathrm{~min}$. The phosphor-specific antibody to ERK1/2 was employed to estimate alterations in ERK1/2 activity induced by GnRH-I and II treatment. GnRH-I and II induced a 4-fold increase in phosphorylation of ERK1/2 (Fig. 1A). To determine the role of the GnRH-I receptor in ERK1/2 activation, cells were pretreated with Antide $(100 \mathrm{nM})$ for $15 \mathrm{~min}$, followed by GnRH-I or II for $10 \mathrm{~min}$. Pretreatment with Antide significantly reversed GnRH-I or II-induced ERK1/2 activation, whereas Antide alone did not alter the phosphorylation of ERK1/2 as seen in Fig. 1A.

To evaluate the role of the GnRH-I receptor in GnRH-induced anti-proliferation, cells were pretreated with Antide, a GnRH-I receptor antagonist, followed by treatment with GnRH-I or II. As expected, treatment with GnRH-I or -II induced a significant decrease of cell proliferation in both SKOV-3 and OVCAR-3 cells. In addition, it is of interest that co-treatment with Antide reversed the anti-proliferative effect of GnRH-I and II in these cells (Fig. 1B), suggesting that GnRH-I or GnRHII-induced anti-proliferation may be mediated by the GnRH-I receptor.

\section{Anti-proliferative effects of GnRH-I and II mediated by the GnRH-I receptor}

To confirm the role of the GnRH-I receptor, the cells were transfected with siRNAs targeting the GnRH-I receptor. The efficiency of siRNA-mediated downregulation of the GnRH-I receptor was monitored by immunoblot analysis. Treatment with GnRH-I receptor siRNA resulted in a significant decrease in GnRH-I receptor expression at the protein level in both SKOV-3 and OVCAR-3 cells (Fig. 2A). In addition, transfection with GnRH-I receptor siRNA blocked the activation of ERK1/2 induced by GnRH-I or II, and scrambled RNA had no significant effect on GnRH-I or-II-induced activation of ERK1/2 (Fig. 2B). Treatment with siRNA of GnRH-I receptor completely reversed the antiproliferative effects of GnRH-I or -II (Fig. 2C), indicating that the GnRH-I receptor is required for both GnRH-I and -II-induced growth inhibition in these ovarian cancer cells.

\section{GnRH-I and -II induced cell activated ERK1/2 in a PKC-dependent manner}

To determine the role of the PKC pathway in GnRH-I and -II-induced ERK1/2 activation, cells were pretreated with GF109203X, a PKC inhibitor, followed by GnRH-I or II. As shown in Fig. 3A, activation of ERK1/2 by GnRH-I and -II was blocked by GF109203X, indicating that GnRH-induced ERK1/2 activation is PKC-dependent. Treatment with a PKCactivating phorbol ester (TPA) induced the phosphorylation of ERK1/2. Pretreatment with GF109203X for 15 min completely abolished the activation of ERK $1 / 2$ by TPA. 
A

\begin{tabular}{c|c} 
SKOV-3 & T-ERK1/2 \\
& P-ERK1/2 \\
OVCAR-3 & T-ERK1/2 \\
& P-ERK1/2
\end{tabular}
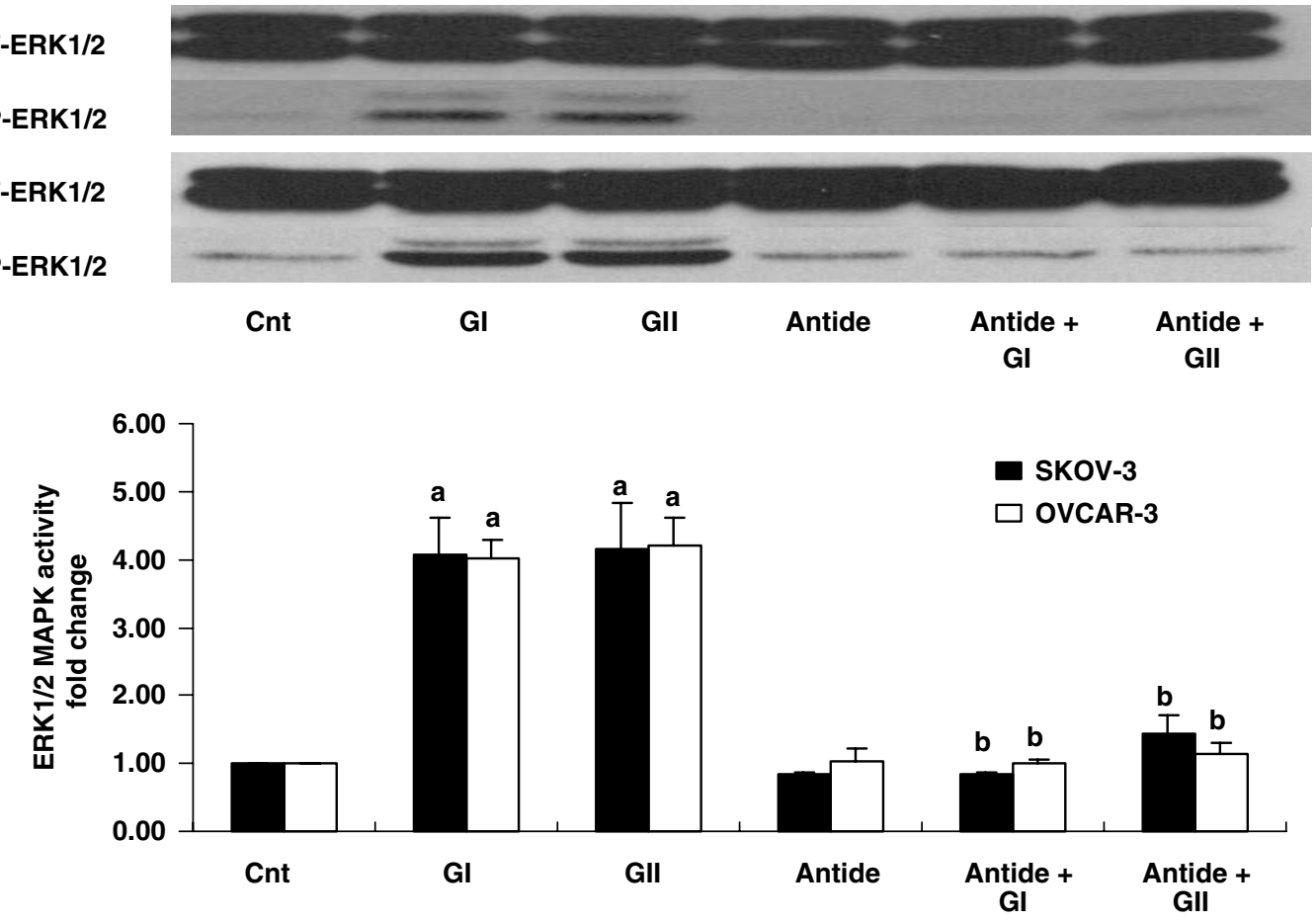

B

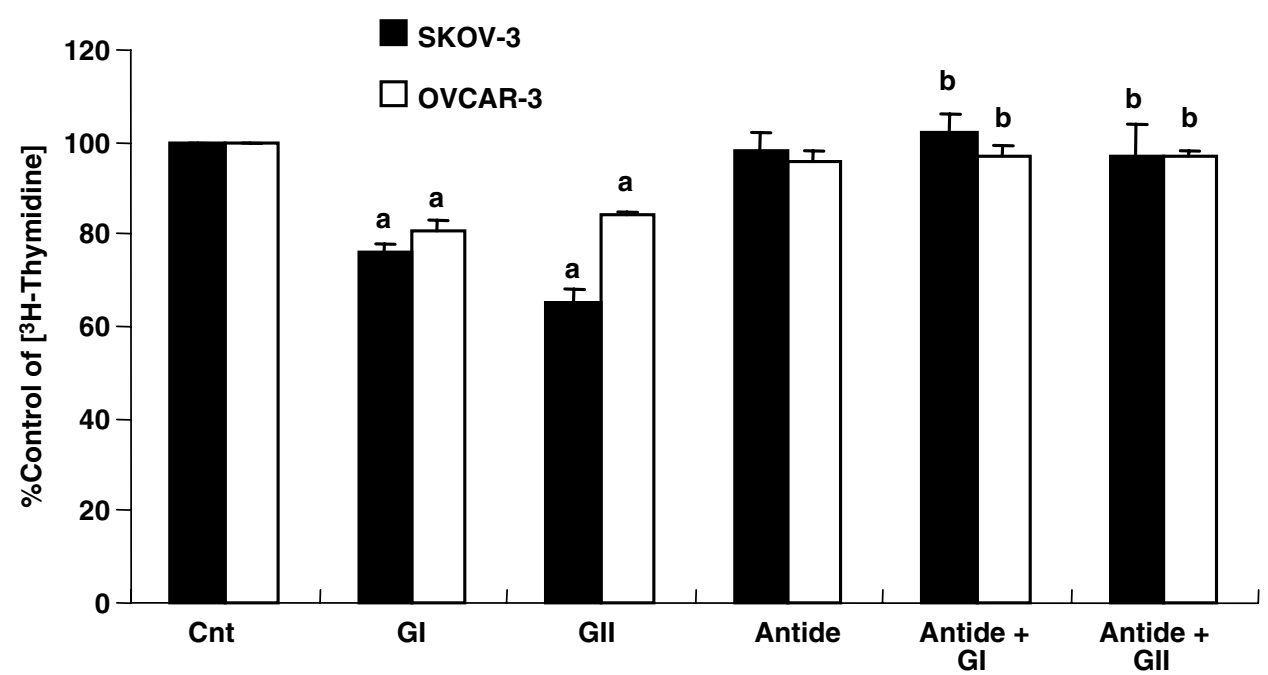

Figure 1 Effect of GnRH-I and II on ERK1/2 activation and growth inhibition in the presence or absence of Antide. (A) OVCAR-3 and SKOV-3 cells were pretreated with Antide $(100 \mathrm{nM})$ for 15 min prior to treatment with $\mathrm{GnRH}-\mathrm{I}(\mathrm{GI})$ or II (GII) at the concentration of $100 \mathrm{nM}$ for $10 \mathrm{~min}$. The T-ERK1/2 and P-ERK1/2 levels were analyzed by immunoblot assay. P-ERK $1 / 2$ levels are expressed as a fold change relative to basal level. Data were analyzed by ANOVA followed by Tukey's multiple comparison test. Values are presented as the mean \pm s.D. of three individual experiments. (B) The cells were treated with $\mathrm{GnRH}-\mathrm{I}(\mathrm{GI})$ or II (GII) at the concentration of $100 \mathrm{nM}$ in the presence or absence of Antide $(100 \mathrm{nM})$, a $\mathrm{GnRH}$ antagonist. A $\left[{ }^{3} \mathrm{H}\right]$ thymidine incorporation assay was performed to quantify s-phase growing cells. The data from three individual experiments are presented as the mean \pm S.D.; $a$, $P<0.05$ versus control (Cnt); $\mathrm{b}, P<0.05$ versus treatment with $\mathrm{GnRH}-\mathrm{I}$ or II alone. 
A

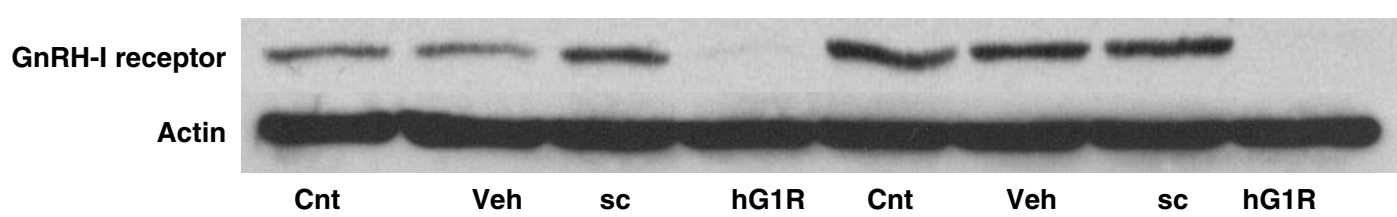

B

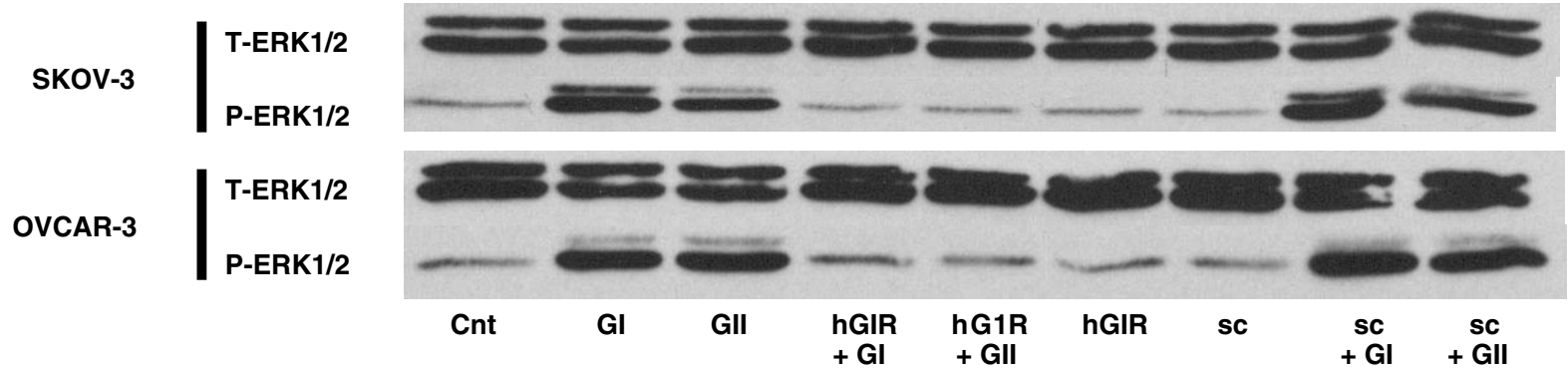

C

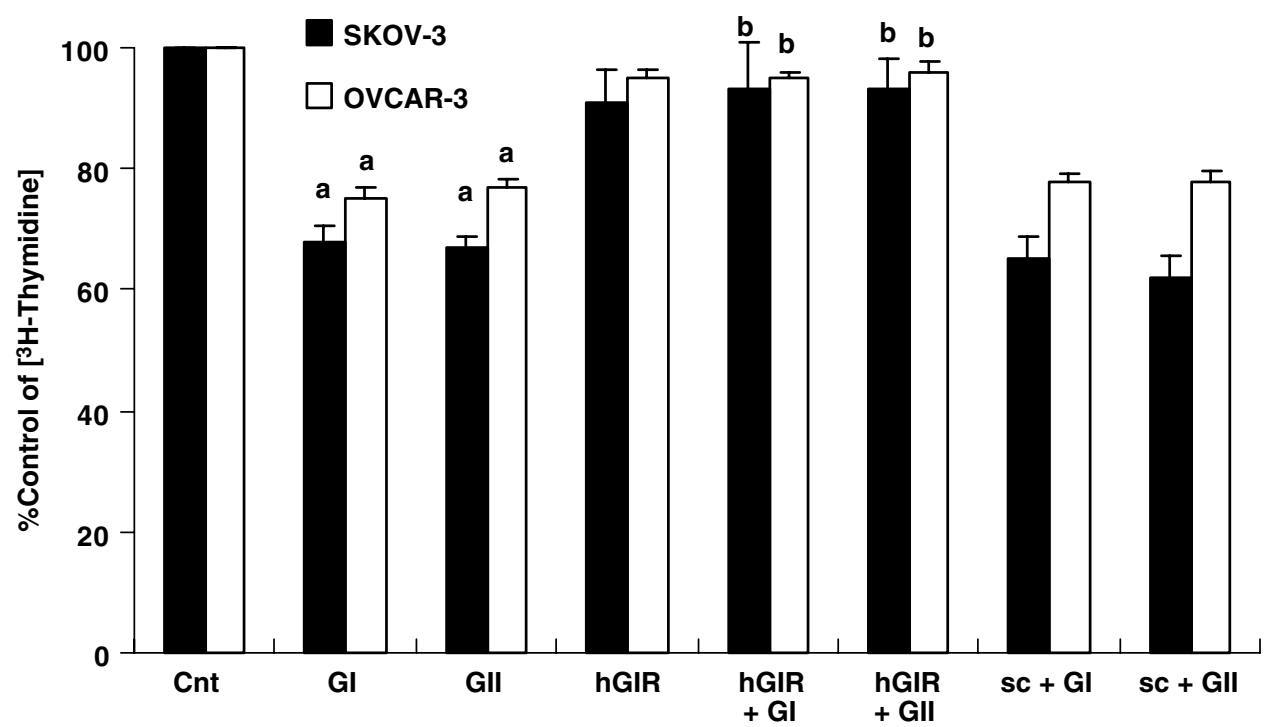

Figure 2 Effect of $\mathrm{GnRH}-\mathrm{I}$ receptor siRNA transfection on $\mathrm{GnRH}-\mathrm{I}$ and II-induced growth inhibition. (A) The cells were transfected with human GnRH-I receptor siRNA (hGIR) or scrambled siRNA (sc) for 1 day with lipofectamine (Vehicle; Veh) and GnRH-I receptor levels were monitored by immunoblot assay. (B) The activation of ERK1/2 induced by GnRH-I (GI) or -II (GII) was monitored after hGIR transfection. (C) To evaluate whether hGIR blocks GnRH-I and II- induced anti-proliferation, cells were transfected with hGIR and treated with GI or GII (100 nM) for $24 \mathrm{~h}$. Cell growth was assessed by thymidine incorporation assay and data are presented as the mean \pm s.D. of three individual experiments. a, $P<0.05$ versus control (Cnt); $\mathrm{b}, P<0.05$ versus treatment with $\mathrm{GnRH}-\mathrm{I}$ or II alone.

\section{Effect of a PKC inhibitor on GnRH-I and II-induced anti-proliferation}

To elucidate the relevance of the PKC pathway in the proliferation of ovarian cancer cells, SKOV-3 and
OVCAR-3 cells were treated with GnRH-I or II $(100 \mathrm{nM})$ for $24 \mathrm{~h}$ in the presence or absence of GF109203X $(0.03,0.3$ or $3 \mu \mathrm{M})$. GnRH-I and IIinduced anti-proliferation was abolished by GF109203X at all concentrations tested, however 
K-Y Kim et al.: GnRHs and PKC on ovarian cancer growth inhibition

A
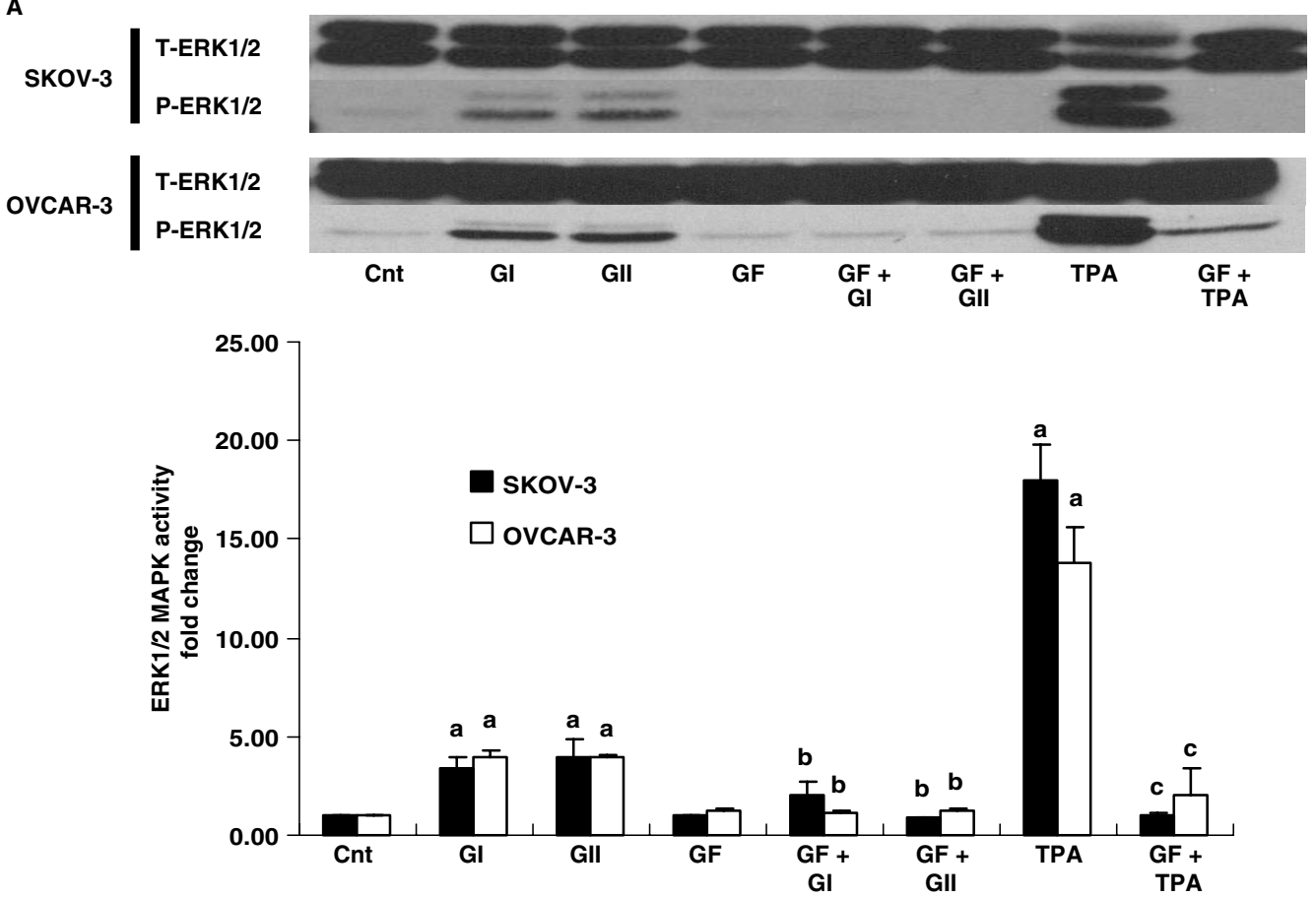

B

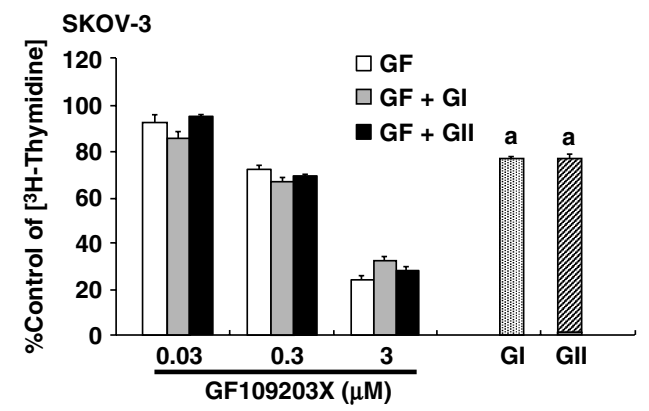

OVCAR-3

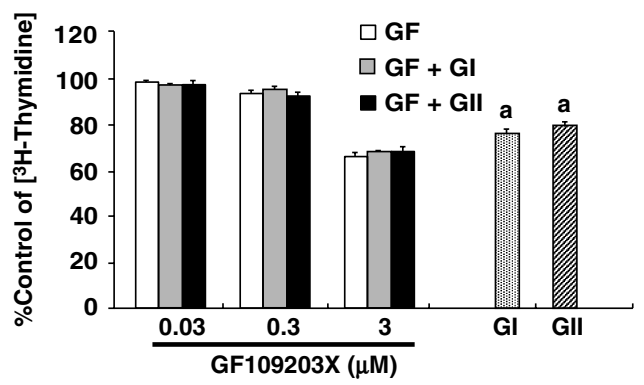

Figure 3 Effect of a PKC inhibitor on GnRH-I- and -II-induced ERK1/2 activation and growth inhibition. (A) The cells were pretreated with GF109203X (GF; $3 \mu \mathrm{M}$ ) for $30 \mathrm{~min}$, followed by stimulation with $\mathrm{GnRH}-\mathrm{I}(\mathrm{Gl} ; 100 \mathrm{nM})$ or $\mathrm{GnRH}-\mathrm{Il}(\mathrm{Gll} ; 100 \mathrm{nM})$ in the absence and presence of phorbol 12-myristate 13-acetate (TPA; $160 \mathrm{nM}$ ) for $10 \mathrm{~min}$. Control cells were treated with vehicle. T-ERK1/2 and P-ERK1/2 levels were analyzed by immunoblot assay. Values are presented as the mean \pm S.D. of three individual experiments. a, $P<0.05$ versus control (Cnt); b, $P<0.05$ versus treatment with $\mathrm{GnRH}-\mathrm{I}$ or II alone; c, $P<0.05$ versus TPA alone. (B) The cells were treated with GI or GIl $(100 \mathrm{nM})$ for $24 \mathrm{~h}$ in the presence or absence of GF109203X (GF; $0.03,0.3$ or $3 \mu \mathrm{M})$. $A\left[{ }^{3} \mathrm{H}\right]$ thymidine incorporation assay was performed to quantify S-phase growing cells. Data are shown as the mean \pm S.D. of three individual experiments. a, $P<0.05$ versus control $(\mathrm{Cnt}) ; \mathrm{b}, P<0.05$ versus treatment with $\mathrm{GnRH}-\mathrm{I}$ or II alone; $\mathrm{c}, P<0.05$ vs. treatment with TPA alone. 
higher concentrations also resulted in a significant decrease in the basal level of thymidine uptake (Fig. 3B), suggesting that the PKC pathway mediates the anti-proliferative effect of GnRH-I and II in these cells.

\section{Discussion}

GnRH-I analogs have long been shown to have direct anti-proliferative effect on ovarian cancer cells (Balbi et al. 2004). Furthermore, it has been reported that GnRH-II has a stronger anti-proliferative effect than GnRH-I in ovarian cancer cell lines, suggesting that GnRH-II could be considered as a novel target for anti-proliferative therapeutic approaches (Grundker et al. 2002). Our previous studies have shown that the ERK $1 / 2$ pathway is involved in the anti-proliferative effect of GnRH-II in ovarian cancer cells (Kim et al. 2005). However, the intracellular signaling generated by GnRH in order to induce the activation of MAPK and anti-proliferation of cancer cells is still poorly understood. In this context, the elucidation of the signaling pathways involved in the anti-proliferative effects of GnRH could provide new therapeutic insights for ovarian cancer prevention and/or treatment. Previous studies have shown that OVCAR-3 and SKOV-3 cells, ovarian adenocarcinoma cell lines, express the mRNA for GnRH-I receptor (Yin et al. 1998, Ngan et al. 1999) and respond to GnRH I (Kim et al. 1999, Kang et al. 2000c). Although the expression of the GnRH-I receptor in SKOV-3 cells is still debated (Grundker et al. 2002), we did not observe any significant difference in the anti-proliferative effect of GnRH-I and II, which prompted the study investigating the role of the GnRH-I receptor.

The GnRH-I receptor is a member of the G proteincoupled receptor (GPCR) family. GPCRs are characterized by the presence of seven transmembrane (7 TM) domains and transmit their signals through multiple $G$ protein subunits $\left(G \alpha_{q}, G \alpha_{s}\right.$, and $\left.G \alpha_{i}\right)$, often activating multiple signaling pathways. The mammalian GnRH-I receptor is unique among GPCRs because it lacks the cytoplasmic carboxylterminal tail that is known to be responsible for internalization and desensitization following ligand stimulation (Millar et al. 2004). A search of the human genome database has revealed a putative GnRH-II receptor gene located on chromosome 1 which shares $40 \%$ identity with the GnRH-I receptor gene (Neill et al. 2001). It is predicted that the GnRH-II receptor may contain a cytoplasmic tail and only five transmembrane domains (5 TM lacking TM I and II) (Neill 2002, Millar 2003). However, a human GnRH-II receptor protein has not been identified since the human GnRH-II receptor transcript has a frame-shift resulting in a premature stop codon (Morgan et al. 2003). Thus, the issue of whether this transcript encodes a functional receptor protein in any human tissue and the potential roles of the GnRH-II receptor in mediating the effects of GnRH-I and II remains obscure. However, there is a discrepancy among the previous reports regarding the role of GnRH-I and II receptors. Enomoto et al. (2004) showed that GnRH-II receptor is required to mediate the effect of GnRH-II, while Grundker et al. (2004) reported that the anti-proliferative effect induced by GnRH-II is not mediated through GnRH-I receptor. On the other hand, a recent study demonstrated that transient transfection with GnRH-II receptor-reliquum inhibited the expression of GnRH-I receptor at the cell surface and impaired signaling via the GnRH-I receptor by reduction of GnRH-induced inositol phosphate accumulation, indicating that GnRH-I receptor may be a common receptor that mediates the effects of both GnRH-I and GnRH-II in ovarian cancer cell lines (Pawson et al. 2005). This discrepancy suggests that the role of GnRH I and II receptors may vary considerably in different cell types or conditions. In the present study, we investigated the role of the GnRH-I receptor and PKC signaling pathway in GnRH-induced MAPK activation and growth inhibition of ovarian cancer cells. In this study, the expression of GnRH-I receptor was monitored by immunoblot assay and the GnRH-I antagonist, Antide, was used to block GnRH-I receptor-induced signaling. Antide is known to exert its antagonistic action in ovarian cancer cells ( $\mathrm{Li}$ et al. 1994) and pretreatment with Antide reduced GnRH-I-induced ERK $1 / 2$ activation in endometrial epithelial cells (Luo et al. 2004).

Although there is a previous report that GnRH-I does not activate MAPK (Emons et al. 1998), others have documented that GnRH-I activates MAPK in various cell types including ovarian cancer cells (Kimura et al. 1999, Kraus et al. 2001). In addition, our previous studies have shown that GnRH-II activates ERK1/2 (Kim et al. 2005) and that this pathway is involved in the effect of GnRH-II on anti-proliferation. In the present study, we found that Antide blocked the activation of ERK $1 / 2$ by GnRH-I, as well as GnRH-II, in OVCAR-3 and SKOV-3 cells. Furthermore, combined treatments of GnRH-I and GnRH-II did not have an additive effect on the activation of ERK1/2 (data not shown). Our present and previous studies have showed that GnRH-I and -II have anti-proliferative effects on 
ovarian cancer cells (Kang et al. 2000a, Kim et al. 2004b) and Antide was used to investigate the involvement of the GnRH-I receptor in GnRH-Iand -II-induced anti-proliferation. Co-treatment with Antide prevented GnRH-I and II-induced antiproliferation. These results are consistent with the hypothesis that the GnRH-I receptor mediates GnRHI and II-induced ERK1/2 activation and antiproliferation in ovarian cancer.

The technique of RNA interference was employed to further examine the role of the GnRH-I receptor in mediating the effects of GnRH-I and II. SKOV-3 and OVCAR-3 cells were transfected with siRNAs targeted against the GnRH-I receptor gene. Immunoblot analysis was used to examine GnRH-I receptor gene expression in transfected cells. The GnRH-I receptor was expressed in the cells treated with vehicle and scrambled siRNA, whereas its expression was significantly reduced in siRNA-transfected cells, indicating that the transcription and translation of the GnRH-I receptor is reduced in these cells. The proliferation of cells transfected with siRNAs was monitored by thymidine incorporation assay. Transfection with siRNAs targeted to the GnRH-I receptor blocked the anti-proliferative effect of GnRH-I and II. These data, together with the effects of Antide, indicate that the anti-proliferative effect of GnRH-I and II on ovarian cancer cells is dependent on the GnRH-I receptor.

The signal transduction pathway activated following the binding of GnRH-I to the GnRH-I receptor have been studied extensively (Millar et al. 2004). The receptor is coupled to the $\mathrm{G} \alpha_{\mathrm{q} / 11}$ protein that activates phospholipase $C \beta$, leading to the activation of PKC and various downstream signal transduction cascades, including the MAPK pathways (Kraus et al. 2001). Activation of the PKC pathway has been well documented in response to GnRH-I stimulation (Andrews \& Conn 1986, Zheng et al. 1994), and GnRH-I induces the translocation of PKC and stimulates enzyme activity (Farshori et al. 2003). Activation of PKC appears to be an important second messenger mediating GnRH-I-induced ERK activation in pituitary cells (Harris et al. 1997) and ovarian cancer cells (Chamson-Reig et al. 2003). In contrast, the GnRH-II signaling mechanism is poorly understood. Our results demonstrate that treatment of OVCAR-3 and SKOV-3 cells with GnRH-I or II for $10 \mathrm{~min}$ resulted in activation of ERK1/2. Furthermore, pretreatment with GF109203X, which inhibits PKC by competing with ATP (Barent et al. 1998), abolished the activation of ERK1/2 induced by GnRH-I, II or TPA. Our results are consistent with the finding that GnRHI activates the PKC pathway in ovarian tumor cells
(Chamson-Reig et al. 2003) and pituitary cells (Sundaresan et al. 1996). Although the PKC isozyme involved in the activation of ERK1/2 by GnRH-I and II in these cells is not yet known, these results suggest that both GnRH isoforms activate ERK1/2 through a PKC-dependent pathway, possibly coupled to the $\mathrm{G} \alpha_{\mathrm{q}}$ protein. In contrast, Kimura et al. showed that the activation of ERK1/2 by GnRH-I appears to be independent of PKC in Caov-3 cells (Kimura et al. 1999). In addition, activation of the c-Jun N-terminal kinase (JNK) pathway was independent of PKC in ovarian and endometrial cancer cells (Grundker \& Emons 2003). This demonstrates that involvement of the PKC pathway is dependent on the cell type and the expression of the required signaling components. To further investigate the role of PKC in GnRHinduced anti-proliferation, we treated ovarian cancer cells with GF109203X in a dose-dependent manner. Inhibition of PKC reversed the anti-proliferative effects of GnRH-I and -II, further supporting the role of activated PKC in the regulation of cellular functions in response to both forms of $\mathrm{GnRH}$ in ovarian cancer cells.

In summary, we demonstrated that Antide and GF109203X blocked the activation of ERK1/2 and anti-proliferation induced by GnRH-I and II. Furthermore, siRNA targeting the GnRH-I receptor abolished GnRH-I and II-induced anti-proliferation. Taken together, our results indicate that the GnRH-I receptor and PKC play an important role in mediating the cellular responses induced by GnRH-II, as well as GnRH-I, in ovarian cancer cells.

\section{Acknowledgements}

This work was supported by the Canadian Institutes of Health Research. P C K L is the recipient of a Distinguished Scholar Award from the Michael Smith Foundation for Health Research. We would like to thank Mr Se-Hyung Park and Beum-Soo An for their technical assistance, and Dr Christian Klausen for critical review of the manuscript. The authors declare that there is no conflict of interest that would prejudice the impartiality of this scientific work.

\section{References}

Andrews WV \& Conn PM 1986 Gonadotropin-releasing hormone stimulates mass changes in phosphoinositides and diacylglycerol accumulation in purified gonadotrope cell cultures. Endocrinology 118 1148-1158.

Balbi G, Piano LD, Cardone A \& Cirelli G 2004 Secondline therapy of advanced ovarian cancer with GnRH 
analogs. International Journal of Gynecological Cancer 14 799-803.

Barent RL, Nair SC, Carr DC, Ruan Y, Rimerman RA, Fulton J, Zhang Y \& Smith DF 1998 Analysis of FKBP51/FKBP52 chimeras and mutants for Hsp90 binding and association with progesterone receptor complexes. Molecular Endocrinology 12 342-354.

Chamson-Reig A, Sorianello EM, Catalano PN, Fernandez MO, Pignataro OP, Libertun C \& Lux-Lantos VA 2003 Gonadotropin-releasing hormone signaling pathways in an experimental ovarian tumor. Endocrinology 144 2957-2966.

Choi KC, Auersperg N \& Leung PC 2001a Expression and antiproliferative effect of a second form of gonadotropinreleasing hormone in normal and neoplastic ovarian surface epithelial cells. Journal of Clinical Endocrinology and Metabolism 86 5075-5078.

Choi K-C, Kang SK, Tai C-J, Auersperg N \& Leung PCK $2001 b$ Estradiol Up-Regulates Antiapoptotic Bcl-2 Messenger Ribonucleic Acid and Protein in Tumorigenic Ovarian Surface Epithelium Cells. Endocrinology 142 2351-2360.

Crespo P, Xu N, Simonds WF \& Gutkind JS 1994 Rasdependent activation of MAP kinase pathway mediated by G-protein beta gamma subunits. Nature 369 418-420.

Emons G, Muller V, Ortmann O \& Schulz KD 1998 Effects of LHRH-analogues on mitogenic signal transduction in cancer cells. Journal of Steroid Biochemistry and Molecular Biology 65 199-206.

Enomoto M, Endo D, Kawashima S \& Park MK 2004 Human type II GnRH receptor mediates effects of GnRH on cell proliferation. Zoological Science 21 763-770.

Farshori PQ, Shah BH, Arora KK, Martinez-Fuentes A \& Catt KJ 2003 Activation and nuclear translocation of PKC[delta], Pyk2 and ERK1/2 by gonadotropin releasing hormone in HEK293 cells. The Journal of Steroid Biochemistry and Molecular Biology 85 337-347.

Grundker C \& Emons G 2003 Role of gonadotropinreleasing hormone $(\mathrm{GnRH})$ in ovarian cancer.

Reproduction Biology Endocrinology 165.

Grundker C, Gunthert AR, Millar RP \& Emons G 2002 Expression of gonadotropin-releasing hormone II (GnRH-II) receptor in human endometrial and ovarian cancer cells and effects of GnRH-II on tumor cell proliferation. Journal of Clinical Endocrinology and Metabolism 87 1427-1430.

Grundker C, Schlotawa L, Viereck V, Eicke N, Horst A, Kairies B \& Emons G 2004 Antiproliferative effects of the GnRH antagonist cetrorelix and of GnRH-II on human endometrial and ovarian cancer cells are not mediated through the GnRH type I receptor. European Journal of Endocrinology 151 141-149.

Harris D, Reiss N \& Naor Z 1997 Differential activation of protein kinase $\mathrm{C}$ delta and epsilon gene expression by gonadotropin-releasing hormone in alphaT3-1 cells. Autoregulation by protein kinase C. Journal of Biological Chemistry 272 13534-13540.
Irmer G, Burger C, Muller R, Ortmann O, Peter U, Kakar SS, Neill JD, Schulz KD \& Emons G 1995 Expression of the messenger RNAs for luteinizing hormone-releasing hormone (LHRH) and its receptor in human ovarian epithelial carcinoma. Cancer Research 55 817-822.

Kang SK, Cheng KW, Nathwani PS, Choi KC \& Leung PC $2000 a$ Autocrine role of gonadotropin-releasing hormone and its receptor in ovarian cancer cell growth. Endocrine 13 297-304.

Kang SK, Choi K-C, Tai C-J, Auersperg N \& Leung PCK $2001 a$ Estradiol Regulates Gonadotropin-Releasing Hormone (GnRH) and its Receptor Gene Expression and Antagonizes the Growth Inhibitory Effects of GnRH in Human Ovarian Surface Epithelial and Ovarian Cancer Cells. Endocrinology 142 580-588.

Kang SK, Tai CJ, Cheng KW \& Leung PC $2000 b$ Gonadotropin-releasing hormone activates mitogenactivated protein kinase in human ovarian and placental cells. Molecular \& Cellular Endocrinology 170 143-151.

Kang SK, Tai C-J, Cheng KW \& Leung PCK 2000c Gonadotropin-releasing hormone activates mitogenactivated protein kinase in human ovarian and placental cells. Molecular and Cellular Endocrinology 170 143-151.

Kang SK, Tai C-J, Nathwani PS, Choi K-C \& Leung PCK $2001 b$ Stimulation of Mitogen-Activated Protein Kinase by Gonadotropin-Releasing Hormone in Human Granulosa-Luteal Cells. Endocrinology 142 671-679.

Kim JH, Park DC, Kim JW, Choi YK, Lew YO, Kim DH, Jung JK, Lim YA \& Namkoong SE 1999 Antitumor effect of GnRH agonist in epithelial ovarian cancer. Gynecologic Oncology 74 170-180.

Kim K-Y, Choi K-C, Park S-H, Chou C-S, Auersperg N \& Leung PCK 2004 Type II Gonadotropin-Releasing Hormone Stimulates p38 Mitogen-Activated Protein Kinase and Apoptosis in Ovarian Cancer Cells. Journal of Clinical Endocrinology and Metabolism 89 3020-3026.

Kim KY, Choi KC, Park SH, Auersperg N \& Leung PC 2005 Extracellular signal-regulated protein kinase, but not c-Jun N-terminal kinase, is activated by type II gonadotropin-releasing hormone involved in the inhibition of ovarian cancer cell proliferation. Journal of Clinical Endocrinology and Metabolism 90 1670-1677.

Kimura A, Ohmichi M, Kurachi H, Ikegami H, Hayakawa J, Tasaka K, Kanda Y, Nishio Y, Jikihara H, Matsuura N \& Murata Y 1999 Role of Mitogen-activated Protein Kinase/Extracellular Signal-regulated Kinase Cascade in Gonadotropin-releasing Hormone-induced Growth Inhibition of a Human Ovarian Cancer Cell Line. Cancer Research 59 5133-5142.

Kraus S, Naor Z \& Seger R 2001 Intracellular signaling pathways mediated by the gonadotropin-releasing hormone $(\mathrm{GnRH})$ receptor. Archives of Medical Research 32 499-509.

Li S, Vuagnat B, Gruaz N, Eshkol A, Sizonenko P \& Aubert M 1994 Binding kinetics of the long-acting gonadotropin-releasing hormone $(\mathrm{GnRH})$ antagonist 


\section{K-Y Kim et al.: GnRHs and PKC on ovarian cancer growth inhibition}

antide to rat pituitary GnRH receptors. Endocrinology 135 45-52.

Luo X, Ding L \& Chegini N 2004 Gonadotropin-releasing hormone and TGF-beta activate MAP kinase and differentially regulate fibronectin expression in endometrial epithelial and stromal cells. American Journal of Physiology, Endocrinology \& Metabolism 287 E991-E1001.

Millar R, Lowe S, Conklin D, Pawson A, Maudsley S, Troskie B, Ott T, Millar M, Lincoln G, Sellar R, Faurholm B, Scobie G, Kuestner R, Terasawa E \& Katz A 2001 A novel mammalian receptor for the evolutionarily conserved type II GnRH. PNAS 98 9636-9641.

Millar RP 2003 GnRH II and type II GnRH receptors. Trends in Endocrinology and Metabolism 14 35-43.

Millar RP, Lu Z-L, Pawson AJ, Flanagan CA, Morgan K \& Maudsley SR 2004 Gonadotropin-Releasing Hormone Receptors. Endocrine Reviews 25 235-275.

Morgan K, Conklin D, Pawson AJ, Sellar R, Ott TR \& Millar RP 2003 A transcriptionally active human type II gonadotropin-releasing hormone receptor gene homolog overlaps two genes in the antisense orientation on chromosome 1q.12. Endocrinology 144 423-436.

Neill JD 2002 Minireview: GnRH and GnRH Receptor Genes in the Human Genome. Endocrinology 143 737-743.

Neill JD, Duck LW, Sellers JC \& Musgrove LC 2001 A gonadotropin-releasing hormone $(\mathrm{GnRH})$ receptor specific for GnRH II in primates. Biochemical and Biophysical Research Communications 282 1012-1018.

Ngan ES, Cheng PK, Leung PC \& Chow BK 1999 Steroidogenic factor-1 interacts with a gonadotropespecific element within the first exon of the human gonadotropin-releasing hormone receptor gene to mediate gonadotrope-specific expression. Endocrinology 140 2452-2462.
Ohmichi M, Sawada T, Kanda Y, Koike K, Hirota K, Miyake A \& Saltiel AR 1994 Thyrotropin-releasing hormone stimulates MAP kinase activity in GH3 cells by divergent pathways. Evidence of a role for early tyrosine phosphorylation. Journal of Biological Chemistry 269 3783-3788.

Pawson AJ, Maudsley S, Morgan K, Davidson L, Naor Z \& Millar RP 2005 Inhibition of human type $\mathrm{i}$ gonadotropin-releasing hormone receptor (GnRHR) function by expression of a human type II GnRHR gene fragment. Endocrinology 146 2639-2649.

Rzepka-Gorska I, Chudecka-Glaz A, Kosmider M \& Malecha J $2003 \mathrm{GnRH}$ analogues as an adjuvant therapy for ovarian cancer patients. International Journal of Gynaecology and Obstetics $\mathbf{8 1}$ 199-205.

Sealfon SC, Weinstein H \& Millar RP 1997 Molecular Mechanisms of Ligand Interaction with the Gonadotropin-Releasing Hormone Receptor. Endocrine Reviews 18 180-205.

Sundaresan S, Colin IM, Pestell RG \& Jameson JL 1996 Stimulation of mitogen-activated protein kinase by gonadotropin-releasing hormone: evidence for the involvement of protein kinase C. Endocrinology 137 304-311.

White RB, Eisen JA, Kasten TL \& Fernald RD 1998 Second gene for gonadotropin-releasing hormone in humans. PNAS 95 305-309.

Yin H, Cheng KW, Hwa HL, Peng C, Auersperg N \& Leung PC 1998 Expression of the messenger RNA for gonadotropin-releasing hormone and its receptor in human cancer cell lines. Life Science $\mathbf{6 2}$ 2015-2023.

Zheng L, Stojilkovic SS, Hunyady L, Krsmanovic LZ \& Catt KJ 1994 Sequential activation of phospholipase-C and -D in agonist-stimulated gonadotrophs. Endocrinology 134 1446-1454. 